\title{
EVALUASI HASIL PELATIHAN DAN PENDIDIKAN UNTUK PENANGANAN PRA RUMAH SAKIT TERHADAP PENDERITA CEDERA
}

\section{(EVALUATION ON THE RESULTS OF TRAINING AND EDUCATION FOR THE PRE HOSPITAL CARE TO THE INYURED PATIENTS)}

\author{
M. Soemarko \\ Lab/SMF IImu Bedah FK unibraw / RSU Dr. Saiful Anwar Malang
}

\begin{abstract}
The purpose of organized trauma system management of pre hospital care of seriously injured patients is to ensure the early intervention and transfer savely the patients to the best equipped facility to care of their injuries. The aims this research is to evaluate the results and the effectiveness of the training and education of pre hospital management in Saiful Anwar Hospital. The method this research are an observational study of injured traffic accident patients preHospital care in Saiful Anwar General Hospital Malang. Training and education have been done intensively and continuously after August 1999 until now. The comparation was between 1st April until 31st Juli 1999 and 1st April until 31st Juli 200. The result of this research, a significant progress in pre hospital treatment, ambulance transportation and communication between field attendance and the trauma center. But significantless of progression in pre hospital medical records. Only reveral system from health center was significant developed. The intensive training and education of pre hospital management to the injured patient had a significant good results. The training and education must be continued and developed for a better results in the future.
\end{abstract}

Key words : Injured patients, pre hospital care, training and education.

\section{PENDAHULUAN}

Semakin dirasakan pentingnya manajemen sistim perawatan trauma pra rumah sakit yang terorganisir dengan baik untuk memastikan penderita yang cedera dapat sampai di instalasi rawat darurat dengan selamat. Keselamatan penderita yang mengalami cedera parah sangat tergantung pada intervensi awal, cara transportasi dengan segala fasilitasnya serta waktu yang diperlukan untuk sampai di rumah sakit yang dituju.

Peran dokter dan perawat yang mempunyai kemampuan khusus dengan pendidikan formal untuk menangani kasus kegawat daruratan baik trauma maupun non trauma telah menjadi kebutuhan yang sangat mendesak pada saat ini, Filosofi lama yang menyatakan "Angkat penderita dan larikan ke rumah sakit" secara pelahan telah berubah menjadi" tetap ditempat dan stabilkan penderita terlebih dahulu". Harus dilakukan perawatan pra rumah sakit dilakukan mulai ditempat kejadian dari kecelakaan lalu lintas(1,2), kecelakaan masal(3) atau bencana alam (4).

Tanpa memandang mekanisme trauma, intervensi harus sudah dilakukan pada tempat kejadian kecelakaan atau dalam perjalanan ke rumah sakit. Yang harus segera dilakukan adalah mengamankan saluran nafas (Airway), ventilasi pernafasan secara efektif, restorasi volume darah sampai derajad tertentu sambil menghentikan perdarahan yang terjadi. Untuk melaksanakan hal ini diperlukan tenaga dokter dan perawat yang terdidik dan trampil melalui pelatihan dan pendidikan yang adekwat.

Trauma adalah suatu proses yang sangat peka terhadap

Jurnal Kedokteran Brawijaya, Vol. XX, No.2, Agustus 2004

Korespondensi: M. Soemarko; Laboratorium IImu Bedah FK Unibraw /RSU Dr. Saiful Anwar Malang, Jl. Veteran, Malang 65145. Telp. 0341-580993; Fax.0341-564755 berlalunya waktu, kemungkinan keselamatan makin menurun, bila waktu perjalanan ke pengobatan definitf makin meningkat. Kematian yang terkait dengan trauma terbagi dalam tiga golongan yang berhubungan dengan interval waktu sejak terjadinya kecelakaan, yaitu :

Kematian segera $(50 \%)$ dari kematian yang terkait dengan trauma).terjadi langsung pada saat trauma, umumnya diakibatkan karena cedera kepala berat atau cedera kardiovaskular. Kematian Dini (30\%) terjadi beberapa jam pertama setelah cedera pada tubuh atau kepala. Banyak kematian dini dapat dicegah dengan perawatan yang tepat. Hasil perawatan dini pada korban akan meningkatan keselamatan penderita melalui stabilisai cepat dilapangan, transportasi cepat ketempat fasilitas perawatan definitif. Konsep the"Golden Hour" ditujukan untuk kelompok ini. Kematian lambat $(20 \%)$ sebagai akibat dari komplikasi infeksi atau kegagalan sistim multiorgan yang terjadi. Hal ini sering berkaitan dengan resusitasi initial yang inadekwat serta secara potensial dapat diatasi dengan perawatan dini yang tepat $(5,6,7)$. Telah diteliti dan dibuktikan di Trauma center University of Virginia bahwa penderita yang mengalami trauma berat apabila dengan segera langsung diangkut ke pusat rujukan trauma maka akan mengalami perawatan di ruang rawat intensif dan waktu opname yang lebih pendek dengan mortalitas yang rendah (8). Untuk Indonesia keadaan seperti ini masih belum memungkinkan oleh karena masih banyak daerah yang terpencil dan jauh dari pusat rujukan trauma sehingga harus diusahakan suatu strategi lain, yaitu mengadakan suatu program pendidikan dan pelatihan.

Manajemen pada korban cedera pra IRD RSSA telah dilakukan pelatihan, dan pendidikan berupa ATLS, BTLS serta Protokol Ambulans untuk meningkatkan kemampuan dokter dan perawat di Puskesmas. Pelatihan dan pendidikan ini kemudian dikembangkan secara intensif dan ditujukan khusus untuk dokter dan perawat di Puskesmas dan Rumah Sakit perifer serta personil 
yang khusus bertugas di ambulans baik milik pemerintah maupun swasta termasuk juga PMI dan POLRI sejak Agustus 1999.

Tujuan penelitian in adalah sebagai penelitian awal terhadap hasil dan efektivitas dari pelatihan dan pendidikan manajemen pra rumah sakit yang dirujuk ke RS Saiful Anwar.dengan membandingkan kinerja dari 1April sampai dengan 31 Juli dari tahun 1999 dan 1 April sampai dengan 31 Juli 2003 untuk melihat kelebihan ataupun kelemahannya.

\section{METODE}

Dilakukan penelitian observasional yang dilakukan dengan pemeriksaan secara "on the spot'dengan rancangan berupa One Group PreTest-PostTest Design. Pada Pre test group dilakukan evaluasi sebelum Treatment. Setelah itu dilaksanakan Treatment yang berupa pelatihan dan pendidikan yang secara lebih intensif dan berkesinambungan sejak Agustus 1999.Untuk Post test group dilakukan pada kurun bulan yang sama pada tahun 2003.

\section{Obyek Penelitian}

Penelitian ditujukan untuk mengamati kinerja SDM pra RS rujukan pada penderita cedera yang dikirim ke Instalasi Rawat Darurat RSUD Dr. Saiful Anwar Malang sebelum dan sesudah pelatihan dokter dan perawat Puskesmas / RS perifer.

Pelatihan yang dilakukan sejak Agustus 1999 sampai dengan Mei 2003:

1. BCLS (Basic Cardiac Life Support) diikuti oleh 40 Dokter dan 1080 perawat dari berbagai daerah.

2. BTLS (Basic Trauma Life Support) diikuti oleh peserta dari Malang dan sekitar nya, Dokter 42 orang, Perawat 91 orang.

3. ATLS (Advance Trauma Life Support) diikuti oleh Dokter umum yang berasal dari dan akan ditempatkan diseluruh Indonesia, sebanyak 1781 dokter.

4. Protokol Ambulans, diperuntukkan pelatihan petugas lapangan khususnya kegiatan unit ambulans, diikuti oleh 3 dokter dan 41 perawat dari Malang.

Hasil pendidikan dan pelatihan yang diukur

1. Terapi yang diberikan ditempat kejadian dan sebelum sampai di IRD RSSA
2. Sistim transportasi penderita dari tempat kejadian/Puskesmas/RS perifer ke RSSA

3. Sistim komunikasi antara Puskesmas/RS perifer dengan IRD RSSA.

4. Catatan Medik penderita pra RSSA

5. Sistim rujukan pra RSSA

\section{Masa Observasi Dan Jumlah Sampel}

Observasi I: Data penelitian pada 1April s/d 31 Juli tahun 1999 $(n=1839)$

Observasi II: Data penelitian pada 1 April s/d 31 Juli tahun 2003 ( $n=1408)$

\section{Analisis data}

Data penelitian berupa prosentasi dari setiap item pada masing masing variabel penelitian. Analisis data untuk mengetahui adanya perbedaan antara Obsevasi I dan II adalah

\section{Paired $\mathrm{t}$ Test.}

\section{HASIL PENELITIAN}

Intervensi terhadap trauma yang diderita penderita harus segera dilakukan dilapangan atau dalam perjalanan harus dilaporkan ke tempat rujukan yang memiliki fasilitas perawatan trauma.

Tercatat pada Tabel 1 dilakukan perbandingan Terapi pra RS antara 1 April s/d 31 Juli 1999 dengan 1 April s/d 31 Juli 2003Pemberian infus, pemasangan bidai, pemberian obat darurat dan penjahitan yang dilakukan pada Puskesmas atau Balai pengobatan sebelum dikirim ke RS rujukan pelaporannya meningkat secara bermakna.

Pada Tabel 2 terdapat penurunan yang bermakna dari transportasi dengan kendara an awam atau umum. Kegiatan ambulans meningkat secara bermakna.

Penurunan cara transportasi penderita dengan memakai kendaraan umum, pribadi atau yang non ambulans cukup bermakna, disertai peningkatan secara bermakna dari ambulans khusus gawat darurat, ambulans puskesmas, balai pengobatan dan RS Swasta. Ambulans PMI aktifitasnya juga meningkat pada kecelakaan di jalan raya.

Tabel 1. Pelaporan pemberian terapi pra rumah sakit

\begin{tabular}{lcccc}
\hline Pelaporan Jenis Terapi yang diberikan & Tahun & Mean (rata-rata / bulan) & Perubahan & $\begin{array}{c}p \text { value } \\
\text { t test }\end{array}$ \\
\hline Pemberian Infus & 1999 & 6 & $+150 \%$ & 0.030 \\
\hline Pemasangan Bidai & 2003 & 15 & +150 & 0.010 \\
\hline Pemberian Pengobatan & 1999 & 2 & $+250 \%$ & 0.0001 \\
\hline Penjahitan luka & 2003 & 7 & 2 & 0.003 \\
\hline
\end{tabular}


Tabel 2. Cara Transportasi Pra Rumah Sakit Rujukan

\begin{tabular}{lcccc}
\hline \multicolumn{1}{c}{ Jenis Transportasi } & Tahun & Mean(rata-rata / bulan) & Perubahan & $\begin{array}{c}p \text { value } \\
\text { t test }\end{array}$ \\
\hline \multirow{2}{*}{ Swadaya } & 1999 & 77 & $-21 \%$ & 0.03 \\
\hline \multirow{2}{*}{ Ambulans 118 } & 2003 & 61 & $+250 \%$ & 0.05 \\
\hline \multirow{2}{*}{ Ambulans Non 118 } & 1999 & 2 & $+53 \%$ & 0.502 \\
\hline \multirow{2}{*}{ Ambulans PMI } & 2003 & 7 & $+50 \%$ & \multirow{2}{*}{0.238} \\
\hline
\end{tabular}

Tabel 3. Komunikasi Ke Rumah Sakit Rujukan

\begin{tabular}{lcccc}
\hline Jenis Komunikasi & Tahun & Mean (rata rata / bulan) & Perubahan & $\begin{array}{c}p \text { value } \\
t \text { test }\end{array}$ \\
\hline \multirow{2}{*}{ Telepon } & 1999 & 1 & $+700 \%$ & 0.001 \\
\hline \multirow{2}{*}{ Radio Medik } & 2003 & 8 & $+110 \%$ & 0.008 \\
\hline \multirow{2}{*}{ Lain-lain } & 1999 & 10 & $+300 \%$ & \multirow{2}{*}{0.028} \\
\hline \multirow{2}{*}{ Tidak Ada } & 2003 & 21 & $-27 \%$ & \multirow{2}{*}{0.020} \\
\hline
\end{tabular}

Pada Tabel 3 terjadi peningkatan yang bermakna pasa komunikasi ke RS Rujukan, peranan telepon genggam sangat besar pada jenis komunikasi melalui telepon, sehingga terjadi peningkatan sampai 7 kali lipat per bulannya. Tanpa melakukan komunikasi sama sekali antara perujuk dengan IRD RSSA tercatat telah terjadi penurunan yang bermakna.

Tabel 4. Pelaporan Catatan Medik Tindakan Pra Rumah Sakit

\begin{tabular}{lcccc}
\hline Pelaporan catatan Medik dari Tindakan Petugas & Tahun & $\begin{array}{c}\text { Mean } \\
\text { (rata rata / bulan) }\end{array}$ & Perubahan & $\begin{array}{c}p \text { value } \\
\text { t test }\end{array}$ \\
\hline Pengukuran Glasgow Coma Scale (GCS) & 1999 & 1 & $0 \%$ & 0.350 \\
\hline Pengukuran Tekanan Darah & 2003 & 1 & $0 \%$ & 0.119 \\
\hline Penghitungan Frekuensi Nafas & 1999 & 1 & $0 \%$ & \multirow{2}{*}{0.471} \\
\hline Penghitungan Nadi & 2003 & 1 & $0 \%$ & \multirow{2}{*}{0.256} \\
\hline Tidak ada Catatan & 1999 & 1 & $-1 \%$ & \multirow{2}{*}{0.180} \\
\hline
\end{tabular}

Pada Tabel 4 tidak ada perubahan yang bermakna pada pelaporan catatan medik pra RS. Hal ini menunjukkan adanya kemungkinan kurang diperhatikannya akan pentingnya masalah ini, karena tak jelas apakah sudah dilaksanakan atau memang tidak dikerjakan. .Pelaporan catatan medik dari tindakan petugas ambulans pra RS sangat diperlukan oleh dokter jaga di rumah sakit rujukan trauma untuk menentukan dan melanjutkan perawatan atau pengobatan pada penderita yang mengalami cedera. Pada Tabel 5 tidak ada perubahan yang bermakna pada asal rujukan pra RS, kecuali dari Puskesmas yang mengalami perubahan secara bermakna. 
Tabel 5. Asal Rujukan Pra Rumah Sakit

\begin{tabular}{lcccc}
\hline Asal Rujukan & Tahun & Mean (rata-rata / bulan) & Perubahan & $\begin{array}{c}p \text { value } \\
\text { t test }\end{array}$ \\
\hline \multirow{2}{*}{ Puskesmas } & 1999 & 8 & $+75 \%$ & 0.001 \\
\hline \multirow{2}{*}{ Rumah Sakit } & 2003 & 14 & $-7 \%$ & 0.890 \\
\hline \multirow{2}{*}{ Kepolisian } & 1999 & 14 & 0.70 & 0.799 \\
\hline \multirow{2}{*}{ PMI } & 2003 & 13 & 4 & 0.169 \\
\hline \multirow{2}{*}{ Cara lain } & 1999 & 4 & $-33 \%$ & \multirow{2}{*}{0.082} \\
\hline
\end{tabular}

\section{DISKUSI}

Penanganan penderita yang mengalami trauma harus dilakukan sejak saat penderita dapat dicapai oleh perawat sebagai petugas penolong pertama yang terlatih telah benar benar difahami, sehingga pada kurun waktu empat tahun sudah ada perbedaan yang bermakna (Tabel 1). Pemberian infus RL, yang ditujukan untuk mengatsi kemungknan terjadinya syok hipovolemik. Pemasangan bidai pada patah tulang ekstremitas ataupun papan datar pada danya dugaan patah tulang punggung. Pemberian oksigen yang merupakan komponen esensial untuk resusitasi jantung, Obat obatan yang diberikan berdasarkan kursus BCLS yaitu epinefrin diberikan perinfus pada penderita yang mengalami bradikardi, atropin pada infark miokard akut, lidokain sebagai anti aritmia atau fibrilasi. Penjahitan luka di Puskesmas atau balai pengobatan sebelum dikirim ke RS rujukan telah terjadi peningkatan yang bermakna. Terjadi pula penurunan yang sangat bermakna dari penderita yang tak mendapat pertolongan, yang dalam hal ini para penderita tersebut tidak ditolong oleh petugas ambulans tetapi oleh masyarakat awam. Ada beberapa tindakan penting yang harus dikerjakan tetapi pada saat itu ( tahun 1999 dan 2003) masih belum dilaksanakan karena belum adanya peralatan yaitu : pemberian oksigen, bag mass ventilator dan Collar brace di Puskesmas/ RS perifer. Peralatan peralatan ini secara bertahap akan dipenuhi pada tahun berikutnya.

Pada sistim transportasi (Tabel 2), terdapat penurunan yang bermakna dari transportasi dengan kendaraan awam atau angkutan umum. Kegiatan ambulans 118 juga nampak meningkat secara tajam dengan dioperasikan beberapa ambulans baru dengan petu gas yang terdidik dan terlatih disamping sosialisasi ke masyarakat untuk menghubungi telpon 118. Untuk kegiatan ambulans biasa (non 118) walaupun di dapatkan ada peningkatan tetapi tidak bermakna, disamping pada umumnya kelompok ambu lans ini juga melaksanakan juga kegiatan pengangkutan penderita non trauma. Dari ambulans palang merah juga tidak didapatkan perubahan yang bermakna dalam kegiatannya mengangkut penderita kecelakaan lalu lintas.

Terjadi peningkatan yang bermakna pada komunikasi pra rumah sakit antara Puskesmas serta rumah sakit perifer (perujuk) dengan IRD RSSA sebagai pusat rujukan trauma (Tabel 3). Hubungan radio medik yang meningkat serta peranan telepon genggam sangat besar pada jenis komunikasi melalui telepon, sehingga terjadi peningkatan sampai 7 kali lipat per bulannya.
Sedangkan tanpa komunikasi sama sekali antara perujuk dengan IRD RSSA tercatat adanya penurunan yang bermakna. Hal ini menunjukkan terjadinya peningkatan konsultasi terus menerus antara perujuk dengan pusat rujukan trauma (IRD RSSA). Konsultasi ini sangat penting karena perujuk dapat berhubungan langsung dengan Doker spesialis dipusat trauma, sehingga penderita lebih cepat akan mendapatkan pertolongan.

Tidak ada perubahan yang bermakna pada pelaporan catatan medik pra RS dapat dilihat pada Tabel 4, hal ini menunjukkan adanya kemungkinan kurang diperhatikannya akan pentingnya hal ini. Pelaporan catatan medik dari tindakan petugas ambulans pra RS sangat diperlukan oleh dokter jaga di rumah sakit rujukan trauma untuk menentukan dan melanjutkan perawatan atau pengobatan pada penderita yang mengalami cedera. Sebetulnya dengan komunikasi lewat E- mail komputer data catatan medik penderita dari Puskesmas/RS perifer dapat langsung diterima di Rumah Sakit rujukan trauma sehingga pada saat penderita sampai di RS rujukan, data penderita sudah cukup lengkap dan sudah ada persiapan untuk memberikan pertolongan pada penderita.

Tidak ada perubahan yang bermakna pada asal rujukan pra RS, kecuali dari Puskesmas yang mengalami perubahan secara bermakna (Tabel 5). Keadaan ini juga perlu untuk diperbaiki karena ini juga menyangkut kelengkapan data penderita. Bila sistim rujukan ini dapat dikembangkan dengan baik maka semua pihak akan mendapatkan keuntungan. Selain penderita yang mendapatkan pertolongan lebih baik karena adanya data yang lengkap, fihak pusat trauma akan mengetahui dengan lengkap asal penderita dan fihak perujuk akan dengan mudah mengakses penderita/keluarga penderita bila ada sesuatu yang belum terselesaikan (misalnya biaya transportasi ambulans atau pengobatan yang telah diberikan) dengan bantuan pusat rujukan yang dituju. Dalam penelitian ini pusat trauma yang dituju adalah RSUD Saiful Anwar karena mempunyai fasilitas SDM dan peralatan terlengkap untuk daerah Malang dan sekitarnya

Untuk Idealnya didaerah Malang terdapat beberapa pusat rujukan trauma yang memiliki SDM terlatih dan Dokter spesialis serta mempunyai fasilitas ambulans yang memadai, karena kematian akibat trauma sangat bergantung pada cepatnya dilakukan stabilisasi penderita, pembebasan jalan nafas, oksigenasi dan pemasangan infus serta medikasi awal. Apabila ternyata didapatkan suatu tension pneumothorax harus segera dapat dilakukan dekompresi pada saat itu juga. Pemantauan 
tanda tanda vital penderita secara berulang, termasuk nadi, tekanan darah, dan saturasi $\mathrm{O} 2$ untuk memastikan oksigenasi dan pemberian cairan yang adekwat. Harus pula diperhatikan adanya kemungkinan cedera pada tulang leher sehingga perlu pemasangan Collar Brace. Semuanya dapat dikerjakan dalam perjalanan ke pusat rujukan trauma (6).

Untuk saat ini selain Kodya Malang yang mempunyai Rumah Sakit dengan fasilitas untuk Trauma yang cukup lengkap, patut dipertimbangkan pula untuk membuat fasilitas rujukan Trauma yang sama di Kodya Batu dan di Kepanjen (Malang Raya), untuk dapat memperpendek perjalanan penderita ke Rumah Sakit. Suatu studi observasi menunjukkan bahwa pada penderita dengan cedera berat yang langsung diangkut ke pusat rujukan trauma akan memperpendek masa inap dan masa perawatan di ICU dan merendahkan mortalitasnya (8). Oleh karena pembuatan pusat rujukan trauma akan memerlukan dana yang tidak sedikit, dapat dibuat alternatif lain yaitu dapat dibuat suatu sistim transportasi rural (9). Suatu usaha pertolongan dan pelayanan ambulans yang melibatkan Puskesmas, Balai Kesehatan Pabrik / tempat wisata yang banyak didapatkan didaerah Malang. Para personil tersebut dapat diikutkan dalam pelatihan dan pendidikan perawatan pra rumah sakit, untuk kemudian semuanya dimotivasi untuk dipadukan dan dilakukan perencanaan sistim rujukan secara mandiri untuk daerahnya sendiri-sendiri. Bila sistim ini dapat berjalan dengan baik, maka tidak mustahil dalam waktu 10 menit dari kecelakaan petugas ambulans sudah sampai di tempat kejadian, dan bila diperlukan segera dikirim ke pusat rujukan trauma yang juga sudah mendapatkan kabar dari radio medik sehingga penderita akan mendapatkan perawatan maksimal dengan cepat dan tepat

Malang merupakan suatu daerah wisata pegunungan, dapat terjadi kecelakaan pada pendakian gunung. Kecelakaan masal akibat bencana gempa bumi atau tanah longsor yang menimpa pemukiman. Kesemuanya memerlukan suatu antisipasi untuk melakukan suatu persiapan pelatihan dan pendidikan yang komprehensif dan lebih disempurnakan.

Mengenai penelitian ini yang merupakan penelitian awal ternyata didapatkan banyak kekurangan dan kelemahannya sehingga untuk penelitian berikutnya, sebaiknya

1. Dilakukan secara berkelanjutan sehingga dampak dari pelatihan dan pendidikan dapat di evaluasi secara lebih teliti dari waktu kewaktu.

2. Dilakukan penilaian terhadap RS rujukan lain apakah kwalitas perujukannya sama dengan perujukan ke RS Saiful Anwar.

3. Melakukan evaluasi pada pengaruh pendidikan dan pelatihan pada dokter dan perawat terhadap lingkungan ditempat kerjanya (misalnya setelah kembali lagi ke Puskesmas).

4. Melakukan evaluasi terhadap pendidikan dan pelatihan itu sendiri untuk dilakukan penyempurnaan. Kursus ATLS / BTLS / BCLS / Protokol Ambulans yang berasal dari Amerika apakah masih memerlukan penyesuaian dengan kondisi Indonesia?.

\section{KESIMPULAN}

Setelah dilakukan pelatihan dan pendidikan yang intensif dan berkesinambungan, telah didapatkan kemajuan yang bermakna pada kinerja sistim pertolongan dan perawatan pra Rumah Sakit, pada penderita cedera yang dirujuk dari Puskesmas atau Rumah Sakit perifer ke RSUD DR.Saiful Anwar Malang sebagai pusat rujukan trauma. Masih diperlukan evaluasi penyempurnaan yang berkesinambungan dari sistim pendidikan dan pelatihan serta selalu memperbarui dan melengkapi sarana dan prasarana penunjangnya.

\section{DAFTAR KEPUSTAKAAN}

1. Davies G. The future of pre-hospital medicine. In: Trauma care. Earlam R. (ed). London: Helicopter Emergency Medical Service; 1997.

2. Cooke MW. How much to do at the accident scene (editorial). BMJ 1999; 319: 1150

3. Kerr GW, Parke TRJ. pre-hospital care at mayor crowd event. Pre-hosp. immed Care 1999; 3: 11-13.

4. Omolu B, Steven DB. Overview of helicopter transfer of injured competitors-15 years experience in the Isle of Man. Pre-hosp.immed Care 1999; 3: 14-16.

5. Coats TJ, Goode A. Opportunity to Improve pre-hospital care in the UK. The Lancet; 17 April 1999: 353: 1292.

6. Dumire R, Peitzman AB. Field Management and Priorities in trauma patient Resuscitation. Surg,Critical Care; Pittsburg, PA; 1-10

7. Frame SB. Prehospital Care, Mattox KL Feliciano DV, Moore EE. (Ed): Trauma; Fourth Edition. McGraw Hill; 2000; $103-126$.

8. Young JS, Bassam D, Cephas GA, Brady WJ, Batler RN. Transfer of Patients in a Rural Trauma System; The American Surg.; Jan 1998; 88-92.

9. Doherty J, Price M. Evaluation of Rural Ambulance Service. World Health Forum; 1998; 19: 315-319. 